\title{
Redacted: The Iraqi War according to YouTube
}

\author{
By Sarah Arnold \\ Fall 2013 Issue of KINEMA
}

\section{REDACTED: THE IRAQI WAR ACCORDING TO YOUTUBE}

Using the increasingly popular format and style of the mockumentary or 'found footage', Brian de Palma's Redacted (2007) aims to present one minor yet horrific event of war through the media with which contemporary audiences are, by this stage, familiar: amateur footage (such as that uploaded to YouTube and other sites daily), video-messaging, news and documentary footage, as well as CCTV and other surveillance footage. The proliferation of such war images may point to the collapsing of spatial and geographical boundaries by bringing the war closer to home and by making it more personal.

Yet, as the film indicates, this very imagery serves to depersonalize war for the spectator-viewer, as well as for the participants and soldiers, who perceive themselves as filmmakers and stars. Indeed throughout the film 'found' excerpts from Arab, French and US media point to the globalized investment in the image rather than the event, the space, or the people. At stake, then, is not merely that war events are manipulated by the media that omit certain images or censor certain events, but that, at the very zero point of the event, media are already a precondition of war. Like the soldier in the film who records and participates in the rape and murder of a family (rather than stopping it), the media stages the war (if only to denounce it later). While Redacted may seek to highlight this, I will suggest that the faux-documentary format employed risks fictionalizing war even further.

The film is a fictionalisation of an actual event: the rape and murder of an Iraqi girl and the murder of her family by American troops near Baghdad in 2006. The film recounts this event mainly from the perspective of a number of soldiers implicated in the event, using faux news footage, home video, online web streaming, CCTV, video calls, and official military interviews. This seemingly fragmented and random footage is edited together to form a relatively linear narrative. Significantly, both 'official' professional broadcast and unofficial amateur videoing are employed. This negates any attempts to consider the film as a specific critique of dominant visual media. However, the film problematizes the visual document in a number of ways. Firstly, as a fiction film, the use of faux documentary aesthetics necessitates a consideration of the very documentary capacity of visual media. By mimicking supposedly factual media formats (factual, that is, in intent) Redacted demonstrates instead the potential 'fauxness' of visual media more generally. Secondly, both 'real' and staged images appear in the film, thus traversing the borders between actual and fictional (I shall return to this point further on). Thirdly, as the film takes pains to suggest, the very recording of a situation inevitably influences the nature of events. All throughout, the film questions the role that the interviewer/reporter/recorder plays in the order of events.

To date, the faux documentary style has been employed predominantly in the horror. More often than not, the purpose of this mode has been to intensify, at least in principle, the emotional and visceral experience for the spectator. At times, these films use the 'found footage' motif in order to suggest that the events recorded are not performances but genuine, archival material. Thus these films might be considered simulacra (Baudrillard, 1983). They point to the reality of archival footage, when archival footage itself has, of course, no such claims upon reality. They uphold the perception of reality media as authentic, as if it could stand in for the real itself. Without dwelling on this topic too much, we might consider how Redacted draws upon this faux documentary mode in a more self-reflexive manner.

Rather unlike the reality horrors of recent years, Redacted contests the factual potential of visual media. Yet, in its very utilisation of the faux documentary aesthetic, it also posits it as having a relationship to a 'truth' or to the reality of the events. For example, in the opening frames of the film the following text appears: "this film is entirely fictional, inspired by an incident widely reported to have occurred in Iraq. While some of the events depicted here may resemble those of the reported incident, the characters are entirely fictional, and their words and actions should not be confused with those of real persons"(emphasis my own). The text 
is then redacted word by word. This is followed by the text "redacted visually documentsimaginedevents before, during and after a 2006 rape and murder in Samarra" (emphasis my own).

While this text might initially seem to distance itself from the actual event, and, indeed, stress the film's fictionality, I would suggest that the very invocation of a 'real' event establishes a causal relationship between a real and a fictional realm. The emphasised words in the aforementioned text indicate the means by which the text shifts back and forth between what is real and what is imagined. In particular, the phrase "visually documents imagined events" further complicated any reading of the film as either actual or fictional. In addition, the film's ending presents 'actual photographs' and thus introduces supposed factual documents into a self-proclaimed fictional text. Some of the photographs visually resemble the film's fictional characters (for example, the 'real' photographs of the body of the pregnant woman and the murdered girl that appear at the end of the film refer to the characters in the narrative).

In Simulations and Simulacra (1984), Baudrillard uses the case of Disneyland in order to claim that America, itself, is false (a simulation). For him, the very' constructedness' of Disney reveals a subversive truth, whereby the surrounding America (and Baudrillard points to Los Angeles) is nothing but hyperreal. In other words, Disneyland functions to give the impression that the rest is real. It conceals the hyperreality of everyday life by offering its staginess as a basis for comparison. Thus, Redacted is constructed as Disneyland to the Iraqi War's America. It might be tempting to suggest that the film demonstrates the unreliability of actual news reporting. After all, in the film the news reporters often reveal only certain aspects of the events. Nonetheless, the film ultimately presents itself as a staged (Disneyland) version of the 'real' (America). De Palma has, indeed referred to 'real images' in interviews. "The true story of the war in Iraq has been redacted from the mainstream corporate media. I did this film because I believe that if we as a country are going to cause such disorder we must also be prepared to face the horrendous images that result from these events." In other words, the real images do not make their way into mainstream media. These mainstream media (in the film's narrative) report war stories in ways that are more palatable for viewers. Yet if the film takes issue with mainstream media, it ultimately suggests that the image is authentic. Indeed, it seems to claim that the lack of images rather than an over-saturation of them results in the 'truth' being obscured.

After all, the variety of media presented during the film evokes a kind of omniscient narration. For example, while the American troops rightfully accused of rape and murder lie about their role in the event, previous amateur footage (taken by another soldier, Salazar) has already confirmed their guilt. Likewise, the combination of news footage from a European channel and an Arabic channel provide a holistic account of the shooting of a pregnant civilian, which is also confirmed by Salazar's recording. Thus, the film seems to propose that images, especially those taken covertly and by amateur recorders, can stand in for the truth.

To return to the Disneyland analogy, the fictional narrative of Redacted infers that 'real life' recordings can tell the truth of the war. To take this one step further, then, images of the Iraqi War offer a sufficient way of understanding it. These images of detainees, of civilian victims, disaster sites, and so on, potentially reveal another aspect of the War that may not be evident in mainstream media alone. This may be true. The case of the photos emerging from Abu Ghraib tends to support such a conclusion. Unofficial images provide an alternative and oppositional construction of the Iraqi War. However, we might remember, and as was emphasised in Errol Morris's Standard Operating Procedure (2007), that these images in fact obscure the truth, or at least offer an easily misinterpretable truth. In a more telling example, the torture images printed in the Daily Mirror in May 2004 proved to be staged. Therefore, if Redacted is to suggest that the image has the potential for truth, then this is perhaps a dangerous game to play.

In fact, the film already seems concerned with the photographic medium's ability to manipulate the referent (although I would suggest that it ultimately disavows this issue and champions the visual image as authentic). More specifically, at a number of points in the film, circumstances are altered by the presence of the camera in a situation. The clearest example of this occurs before and during the rape and murder of the girl and murder of her family. The lead-up begins during Salazar's recording of the soldiers' poker game. Two drunken soldiers suggest returning to a house which they raided earlier in the week. One of them, Rush, openly refers to his desire to return for the Iraqi girl. Another Flake calls her a 'spoil of war'. It is clear that Flake and Rush have discussed this prior to the game. The two other soldiers, Gabe and McCoy, challenge Rush and Flake on this and initially refuse to return to the house. During the conversation Flake turns to 
Salazar, who is still recording, and tells him to turn the camera off. Gabe looks to the camera and demands that it be left on.

This exchange would seem to propose that the camera has the capacity to regulate the soldier's behaviour. Flake begins to self-monitor in front of the camera as he realises that, should his transgressions occur 'on the record', there may be consequences. Similarly, Gabe believes that the documentary capacity of the camera will not only serve as evidence of their behaviour, but that Rush and Flake will not pursue their objective of rape should the camera maintain its regulatory hold over them. In any case, Salazar pretends to turn the camera off (leaving it recording from a nearby chair), and so the soldiers continue with their plan to break into the house in order to rape the girl.

Thus, the film has a curious relationship with the concept of surveillance. In one sense, it is possible to read this in relation to Michel Foucault's theorisation of the panopticon (1977). After all, it is not so much that 'somebody' is watching. Instead, the camera functions as the panopticon's tower. There may or may not be an individual spectating. Rather, it is the insinuation of a spectator which causes the subject to regulate its own behaviour. The soldiers self-monitor when there are cameras recording them. In the earlier raid on the same house, an embedded Arabic reporter asked Rush what he was looking for. Rush, looking towards the camera, claims that he is looking for signs of insurgency- documents that will confirm the homeowner's guilt. It is clear that he is panicking. He picks up Arabic documents in order to demonstrate that he is doing his job. In other words, he carries out his job in order to satisfy the hypothetical spectator. Similarly, Flake's concern with Salazar's camera suggests a concern with this same hypothetical spectator. Flake carries on his conversation with Salazar without restraint. It is Salazar's camera which causes him to hesitate.

In Discipline and Punish (1977), Foucault argues that the panopticon functions to exercise power without the effort of instituting that power on an individual or personal level. The individuals whom this power serves need not enact that power corporally. The surveillance system guarantees that there need not be any constant surveyor. This results in the individuals surveyed enacting a form of self- regulation. As Foucault goes on, "He who is subjected to a field of visibility, and who knows it, assumes responsibility for the constraints of power; he makes them play spontaneously upon himself; he inscribes in himself the power relation in which he simultaneously plays both roles; he becomes the principle of his own subjection"(1977, p. 217). The soldiers of Redacted, at times, 'assume the responsibility' of surveillance, they project an external performance of subjection and compliance. Yet, the system fails precisely at that point when the surveillance becomes covert. Salazar, at times, intrudes upon the space of the soldiers, asks them to perform for the camera, and identifies himself as an aspiring filmmaker. However, he secretly records the soldiers on a number of occasions.

Firstly, he accidentally records Flake killing the civilian at a checkpoint. He then records the conversation at the poker game, and finally, he records the rape of the girl. In the latter two cases, the film infers that it is precisely the lack of open surveillance that results in the soldiers' actions. Salazar claims, to the opposing others, that he will go with Rush and Flake to record their actions in order to make them accountable. He mounts a camera on his helmet and performs the role of accomplice. Yet, the distinction between performance and actual complicity is troubled by the film. Salazar's refusal openly to record the soldiers is, in fact, a contributing factor to the rape and murders. Therefore, we might read the film as a promotion of increased open surveillance of the soldiers. Salazar becomes embroiled in the rape because he does not call attention to his camera. During the rape Rush tells him to hold the girl down. Since Salazar wants to record the rape so that its revelation will help him get into film school, he complies. And, so, the mechanisms of power (over the soldiers) fail at precisely the point during which surveillance disappears/becomes hidden. As Foucault suggests, such power can only be exercised on a continual basis.

This relationship between war and media is further complicated through the repetition of media and news narratives (of the soldiers' lives, of the rape and murders, and of the killing of the pregnant civilian). In particular, Salazar is initially disappointed that he has failed to record any material that might boost his filmmaking profile. Early on, he begins to direct his colleagues' performance on camera, asking them to read excerpts from books and recount their experiences. These soldiers perform accordingly for the camera. Throughout Salazar's videos, soldiers attempt to draw the camera towards themselves, pose, perform in a theatrical manner, and direct the camera towards particular scenes. Flake, for example, holds his hand out 
to the camera during Salazar's interview. He moves closer to the camera in order to emphasise certain points and he also opens up the frame to other characters in order to expand the scene. In this staging and framing by both recorder and recorded, the film undermines the camera's documentary mode.

In many of the media segments, narratives are imposed on the image in order to imbue the visual with a sense of meaning and purpose. The jihadists' website utilises performance and violence in similar way to Salazar. Here again, the soldiers are the unwitting participants, yet the jihadists enact the performance, broadcasting their beheading of Salazar for recruitment purposes. The staging of the improvised explosive device detonation and the beheading of Salazar are accompanied by music and narration respectively, turning the event into the performance of victory.

In the French documentary (which follows the same soldiers), the narrative, in fact, seems at odds with the images presented. The narrator details the soldiers' daily tasks and emphasises the dangers they face in their work. Yet, the accompanying images detail the boredom of the soldiers, as well as the lack of intensity and drama. Similarly, the news reports present alternative narratives of particular events. The "Central Euro News" (as this fictional news source is called in the film) sanitises the killing of Salazar, simply claiming that he had been kidnapped and tortured. The Arabic ATV news (another fictional news source) provides further details of the motives for Salazar's death (a revenge killing in response to the rape and murders) and broadcasts the beheading of Salazar. However, both only provide partial access to the 'real' event, as recorded by Salazar and CCTV of the soldiers.

Thus, any 'reality' of war becomes inaccessible through any one medium. It may be the project of the film to note how mainstream media distort and censor images of war, but, at the same time, the film enacts a hyperreal claim that this 'reality' can potentially be accessed, through participatory media (in which the 'user' becomes the media producer as in the case of the Youtube-like footage which eventually exposes the events). The amateur footage, which includes segments of various video-hosting websites, as well as videoconferencing technology, offers a response to mainstream media. Here, participants can utilise the democratic potential of new media in order to step out of the passive spectatorial role that mainstream media constructs for viewers. However, as is clear, this democratic new media may also be used for subversive purposes (as in the case of the jihadists). While participatory media may be used to undermine violent State or military regimes, it also has the potential to promote the very violent activity seemingly condemned within the film.

Digital interactive media may offer alternative forms of democratic participation but Redacted problematizes as much as it promotes them. Therefore, what truth might be revealed in these images, if any at all? The film proposes that media worryingly construct war narratives, and, in fact, encourages the performance of war by those who participate in it. Baudrillard had foreseen this tendency towards simulation of war in his readings of the Gulf War (Baudrillard, 1995). For him, and like Redacted, the war is simulated not only at the level of reception (the TV image constructs the war) but at the level of production (the military perform war both for the media producers, as well as in their use of imaging technology which enables them to view their participation in the war as though it were media). Yet, the film itself proposes, on the one hand, that media participation in a war alters its outcome, but, on the other, that some fundamental truth emerges from the cross-section of various media.

Here I will return to the film's use of 'actual photographs' of the war, the final images attached to the end of the fictional narrative. Instead of reading these as the truth to which the fictional film refers, it might be read, given the performativity of war, that the spectator reads these as images to which some truth refers. In other words, the 'actual photographs' are perceived as no more real than the preceding fictional film. What we are finally left with is not a polemic on the role of media in the war, but, perhaps, the performative role of war in the media.

\section{References}

Baudrillard, Jean. Simulations, Trans. Paul Foss, Paul Patton, Philip Beitchman. New York: Semiotext(e), 1984. 
. The Gulf War Did Not Take Place, Trans. Paul Patton. Bloomington: Indiana University Press, 1995.

Foucault, Michel. Discipline and Punish: The Birth of the Prison, Trans. Alan Sheridan. New York: Vintage, 1977 and 1995.

Redacted. Director: Brian de Palma. Produced: The Film Farm, HDNet Films, USA, 2007.

Standard Operating Procedure. Director: Errol Morris. Producer: Sony (co-production), USA, 2008.

\section{Author Information}

Sarah ARNOLD is Lecturer in Film \& Digital Media at Falmouth University, Cornwall, UK. She currently teaches on Criticism, Analysis and Theory; Postmodernism, Film and New Media, History of the Moving Image: Future. Her recent publications include Maternal Horror: Melodrama and Motherhood (Palgrave McMillan, 2013) and The Film Handbook (Routledge, 2013) co-authored with Mark De Valk. She has contributed book chapters such as Tainted Love: Screening Sexual Perversities (I. B. Tauris, 2013) and Bound by Love: Familial Bonding in Film and Television since 1950. 